\title{
Information Content of Earnings in the Emerging Capital Market: Evidence from the Warsaw Stock Exchange*
}

\author{
Eva K. Jermakowicz \\ University of Southern Indiana, U.S.A. \\ Sylwia Gornik-Tomaszewski \\ Baldwin-Wallace College, U.S.A.
}

\begin{abstract}
This article investigates the association between stock returns and the annual earnings, derived from the new accounting and reporting standards, of firms listed on the Warsaw Stock Exchange between 1995 and 1997. Following a brief history of the Warsaw Stock Exchange, two major issues affecting the effectiveness of the Polish securities market are discussed. These are the transition process from public to private enterprise ownership, and the development of accounting and reporting standards compatible with the capital market requirements and the European Union regulation. The empirical results indicate a significant association between stock returns and annual earnings. Results are compared with those for more developed capital markets.
\end{abstract}

Keywords: accounting and reporting standards Poland, earnings and returns, privatization, Warsaw Stock Exchange.

\section{Introduction}

Privatization is a rapidly growing phenomenon. It is a broad concept encompassing the transfer of property rights from the state to enterprises and individuals. Privatization programs have been started in a number of the Organization for Economic Cooperation and Development

\footnotetext{
*The authors would like to thank the editors and the reviewers for their helpful comments and suggestions.
}

(Multinational Finance Journal, 1998, vol. 2, no. 4, pp. 245-267)

(C) Multinational Finance Society, a nonprofit corporation. All rights reserved.

DOI: $10.17578 / 2-4-1$ 
(OECD) countries as well as in Africa, Asia, Latin America and, most recently, in Central and Eastern Europe. It is a key element in the transition to a market economy.

The major objective of privatization is to strengthen market forces and competition within the economy, improve enterprises'performance, and enhance domestic financial markets by building a wider business ownership base. In countries where the usual method of raising capital is through debt financing with banks and government agencies, privatization through share offerings is an important strategy for developing financial markets to attract investment capital and encourage efficient utilization of national resources.

Since 1990, as the result of the transition of post-communist countries from centrally planned economies to market economies, stock exchanges have been opened in Hungary, the Czech and Slovak Republics, Poland, Romania, Bulgaria, and the former Soviet Union republics.

The emerging capital markets in the post-communist countries are very small by the standards of Wall Street, London, and Tokyo, but they can be a major source of capital for economic growth and development. Besides the economic development role, the emerging markets may provide external investors with a good source of diversification for international portfolio management. The International Finance Corporation, a development institution of the World Bank, has been actively involved in the development of emerging markets.

Poland was selected for this study as one of the most advanced in the privatization process among Central and East European countries (World Investment Report, 1994). In addition, it received the status of associate member of the European Union (EU) and is seeking full membership in the EU by the year 2000 (Articles 68-70 of the EU, 1994).

In January of 1995 a new Act on Accounting replaced the existing accounting law in Poland. The new law assures full compliance of the Polish accounting system with the EU regulation. Several major changes to existing accounting and reporting practices were introduced, including the standardization (with allowed variations) of the measurement and disclosure of financial results. The Act defines structural elements and economic content of these elements of net income (net loss). Specifically, the requirement to calculate and present 
operating income is emphasized (Koc and Borkowska, 1994).

The purpose of this article is to present empirical evidence on the association between stock returns and earnings, calculated under the new accounting regulation, for a representative sample of firms listed on the Warsaw Stock Exchange (WSE). The degree of this association will indicate how earnings, derived from the new accounting and reporting standards, are reflected in market values. The findings can assist standard setters in Poland in evaluating the effectiveness of the new accounting and reporting standards. They can also be useful for domestic and international investors in evaluating risk associated with presence in the Polish capital market.

The remainder of this article is organized as follows. The next section presents the development of the WSE and discusses the Polish experience with the privatization process. Section III discusses the evolution of Polish accounting standards. In Section IV, the description of the sample, data sources, and research design is followed by the presentation of the results of the data analysis. The last section provides the summary and conclusions.

\section{Development of the Warsaw Stock Exchange}

The 52-year hiatus in the functioning of the capital market in Poland created a legal and institutional void. There was a lack of experience and professional knowledge accompanied by enormous potential for development.

After considering many alternative routes, the Polish organizers decided to look at various foreign models of capital market operations and adopt the most up-to-date methods of legal regulation and organization. However, it was also recognized that any adopted system must be relevant to Poland's situation. Following an in-depth review of several contemporary securities markets, a system based on French experience was adopted and implemented with the help of experts from the Societè de Bourses Françaises and the French Depository SICOVAM. The WSE is patterned after the Lyon Stock Market located in France, because of its flexible system and the fact that the organizers were the most familiar with this system.

The WSE was reopened on April 16, 1991, some 52 years after its 
closure in 1939. Before 1939, Poland had six stock exchanges, but 90 percent of all trading was executed on the Warsaw exchange, which had originally been founded in 1817 . The new Polish government chose to locate the stock exchange in the building formerly occupied by the Communist Party's Central Committee.

On April 12, 1991, the Act establishing the WSE was signed, and on April 16, 1991, the first trading session took place. During this session, shares of five companies were traded by seven brokerage houses. By December, 1997, the shares of more than 200 companies were listed. The method of large-firm privatization followed at the early stage of privatization - modeled on the British experience - turned out to be rather slow and cumbersome, and it gave way to discussions of other methods, such as direct sale of shares to foreign firms and mass privatization.

A vital element in the creation of the capital market was its legal framework, which had to be established right from the start. After much international consultation and informal and formal debate in Poland, the Act on Public Trading in Securities and Trust Funds was adopted by the Polish Parliament on March 22, 1991. This Act provided the basis for the main components of the capital market: brokerage houses, the stock exchange, trust funds, and the Polish Securities and Exchange Commission (Komisja Papierow Wartosciowych). The latter is the organ of governmental control and promotion of the capital market. To be listed on the exchange, a company must first conform to the specific standards issued by this commission.

The admission of securities for trading requires a resolution of the Exchange Supervisory Board. The Board also decides on which market (main, parallel, or free) the securities will be traded. When considering a market type, the board takes into account: value of the issue, its transferability, dispersion of ownership, book value and share capital of the issuer, as well as profitability of the issuer. Table 1 contains a comparison of basic minimum requirements for admitting securities for trading on main, parallel, and free markets of the WSE. ${ }^{1}$

Although accounting and reporting standards are established in Poland by the Accounting Department of the Ministry of Finance, the

1. There is also a fourth market present on the WSE, the Derivative Rights market, where futures, options, and warrants are traded. Because of its different character, this market was not included in the analysis. 
TABLE 1. Minimum Requirements for Trading Securities Trading on the Main, Parallel, and Free Markets of the Warsaw Stock Exchange

\begin{tabular}{lccc}
\hline Minimum Requirement & Main & Parallel & Free \\
\hline $\begin{array}{l}\text { 1. } \begin{array}{l}\text { Value of shares to be } \\
\text { admitted (Pzl millions) }\end{array} \\
\begin{array}{l}\text { 2. Book value of the issuer } \\
\text { (Pzl millions) }\end{array}\end{array}$ & 24 & 12 & 4 \\
$\begin{array}{l}\text { 3. Share capital of the issuer } \\
\text { (Pzl millions) }\end{array}$ & 10 & 5 & 4 \\
$\begin{array}{l}\text { 4. Number of shareholders } \\
\text { owning the issue }\end{array}$ & 500 & 300 & 1.5 \\
$\begin{array}{l}\text { 5. Issuer's combined pre-tax profit } \\
\text { for the last 3 years (Pzl millions) }\end{array}$ & 8 & $\mathrm{n} / \mathrm{a}$ & $\mathrm{n} / \mathrm{a}$ \\
$\begin{array}{l}\text { 6. Last year pre-tax profit required } \\
\begin{array}{l}\text { Public disclosure of audited } \\
\text { annual financial reports by the } \\
\text { issuer (number of years) }\end{array}\end{array}$ & yes & yes & no \\
\hline
\end{tabular}

Note: The " $\mathrm{n} / \mathrm{a}$ " indicates no specific requirement in the regulatory framework.

Securities Commission provides disclosure requirements. Companies listed on the WSE must make a public announcement to both the Securities Commission and the Polish press agency of any information likely to affect share prices within 24 hours. Companies also have to submit preliminary copies of interim and full-year financial statements to the Securities Commission.

Polish authorities tried to integrate capital market infrastructure development with the gradual privatization process, with the intent to establish the high disclosure and fiduciary standards typical of the mature securities markets. This approach was criticized by some as overambitious, costly, and holding back the trading activity. For example, one of the listed companies, E. Wedel. SA, owned mostly by PepsiCo, recently discontinued trading securities on the WSE in order not to comply with all the regulations since this company was no longer interested in raising capital through new stock issuances (Penetrator, 1997).

In December, 1991, the WSE became a corresponding member of 
the International Federation of Stock Exchanges (FIBV) and the Federation of European Stock Exchanges (FESE). On October 10, 1994, the WSE became a full member of the FIBV. It was the first stock exchange from Central and Eastern Europe to be given such status.

The first years of the WSE lured investors by a promise of dazzling returns. The WSE index, WIG, jumped by 164 percent in 1993 with the culmination point in January, 1994, when shares in Bank Slaski, the second state bank privatized, soared on its first day of trading by an astonishing 1250 percent, inciting accusations of insider trading and charges of political corruption (Rzeczpospolita, 1994). ${ }^{2}$ However, during the next two years, the market has almost half of its value (Penetrator, 1995).

The Polish Mass Privatization Program (MPP), which was enacted by the Parliament in 1994, accelerated the development of the capital market in this country. This program aims to promote the development of profitable and valuable companies by a cost-effective method of privatization; that is, by creating financial intermediaries called National Investment Funds (NIFs). The main goal of the NIFs is to increase the value of their assets, which were composed of the shares of companies created upon transformation of state-owned enterprises. Five hundred and twenty-eight enterprises were selected for privatization under this program. In principle, the Ministry of Privatization selected enterprises larger than the average Polish enterprise that indicated their desire to take part in the program. The MPP specified that a free distribution of participation certificates would be exchangeable for shares in selected companies. Fifteen NIFs were created under this program. Since inception in 1995, all of them are listed on the WSE. The NIFs operate as holding companies having initially 33 percent of shares (lead shareholdings) of 25 enterprises and about 5 percent of shares (minority shareholdings) in all other enterprises designated for this program (Thieme, 1995). Although ownership in the MPP companies is widespread, consolidation of shareholdings in the marketplace took place during the last two years, limiting the influence of the State Treasury (Penetrator, 1997).

2. The inflation rates in Poland in 1993 and 1994 were $37.7 \%$ and $29.5 \%$, respectively. The inflation rate for the month of January, 1994, was $1.9 \%$. 
TABLE 2. Main, Parallel, and Free Markets During the 1995-1997 Period

\begin{tabular}{lcccc}
\hline Market Size & Year & Main & Parallel & Free \\
\hline Number of listed companies & 1995 & 53 & 12 & 0 \\
& 1996 & 66 & 17 & 0 \\
& 1997 & 96 & 29 & 3 \\
Average capitalization & 1995 & 9,030 & 346 & 0 \\
(PLZ millions) & 1996 & 19,351 & 712 & 0 \\
& 1997 & 33,601 & 1,665 & 80 \\
Total turnover value & 1995 & 12.2 & 1.08 & 0 \\
(PLZ millions) & 1996 & 25.61 & 2.46 & 0 \\
& 1997 & 36.04 & 5.64 & .3 \\
\hline
\end{tabular}

Note: Data for the main market does not include shares of National Investment Funds $(N I F \mathrm{~s})$.

Table 2 presents the number of companies listed on the main, parallel,and free markets (between 1995-99) of the WSE, the average capitalization of these companies, and their total turnover value. The data underlines the importance of the main market, with the parallel market catching on. The free market, which was created for starting companies with limited capital, picked up just recently.

\section{Evolution of Polish Accounting Standards}

Accounting and financial reporting generally play an important role in enhancing and supporting the privatization process as well as the development and growth of the securities market. It is always necessary to file a registration and prospectus in order to be listed in any securities market. The registration and prospectus contain financial statements and supporting schedules. In most cases the financial data must be certified by professional accountants or government inspectors. Accounting information and financial reporting usually deal with past events and require that adequate accounting standards be applied to summarize and valuate the financial position and results of operation of the registered company. On the other hand, an efficient and effective capital and securities market requires information useful for predicting future cash flows from operations. Therefore, accounting information 
regarding past transactions will only be relevant if it is useful in anticipating future outcomes. To have a dependable securities market, accounting and reporting should include a series of disclosures regarding the current value of the public companies as well as limitations of the information presented in financial reports.

Polish accounting and financial reporting standards are in a state of transition. In the past, accountancy served to provide information to the government at various levels for planning purposes, for allocating resources, and for monitoring the plan. State enterprises followed a uniform accounting system with a standardized chart of accounts. Because of the limited reasons for accounting, the role of the accountant was primarily that of bookkeeper. The system focused on a legal form of the accounting transaction rather than on economic substance (Rolfe, Doupnik, 1995). No tradition existed to account for interest, which was considered an instrument of capitalistic exploitation. The word "capital" was prohibited ideologically. Goodwill and other intangible assets were not recognized nor were equity and long-term debts clearly distinguished. State-owned enterprises generally followed fund-based accounting practices because the state was the sole owner of companies.

Accounting reform is an integral part of economic reform. During Poland's transition to a market economy, two themes dominated economic changes: an opening to the West with accompanying attempts to attract Western capital, and the privatization of ownership and managerial decision making. Privatized companies, investors, creditors, and all other third parties have created the need for reliable and accurate financial information. External pressures for change in accounting standards arise from the need to attract foreign loans and investment guarantees. The World Bank and International Monetary Fund (IMF) play key roles in promoting changes. From the standpoint of a prospective investor, accounting information should be reliable, consistent with international accounting standards, and useful for making investment and credit decisions. The usual mode for providing such information is through financial statements that present a true and fair view of the status of enterprise resources, claims to resources, changes in resources, and the nature and timing of cash flows. According to Choi and Levich (1991), the harmonization of accounting standards should facilitate the internationalization of capital markets and multinational businesses because it can provide comparable 
financial information for international users.

The previous statistical reporting system existing in Poland has not been swept aside with a new legislation designed to replace it, but rather additional accounting regulations considered more appropriate to an emerging market economy have been superimposed upon it. Not all of this additional legislation is new. The Decree of the President of the Republic of June 27,1934: The Commercial Code (Rozporzadzenie Prezydenta Rzeczypospolitej z dnia 27 czerwca 1934r.: Kodeks Handlowy), for example, represents a reintroduction of legislation which was enacted in 1934 during the Second Republic (1918-39). Based upon German precedent and a progressive piece of legislation for the time, the Kodeks Handlowy lays down reporting and disclosure rules of a very general nature only.

Important changes in accounting standards occurred on October 19, 1990, when new accounting principles officially incorporating the Fourth Directive of the European Union (EU) on the "true and fair" view criterion for preparation and presentation of financial statements were promulgated (Rozporzadzenie, 1990).

The new Act on Accounting (Ustawa o Rachunkowosci) which was enacted by Parliament on September 29, 1994, and became effective January 1, 1995, constitutes a significant step toward incorporating Western accounting standards. The purpose of this Act was to introduce full compliance of existing standards with the EU regulations, including Directives IV on annual accounts of companies, VII on consolidated financial statements, Directive 86/635 on financial statements for banks and other financial institutions, and Directive 91/674 on financial statements of insurance companies. The introduction of full compliance was a commitment Poland made when receiving the status of associate member with the EU in 1994; it will seek full membership around the year 2000 (Articles 68-70 of the EU, 1994). The general preamble to the Polish Act on Accounting states that new accounting standards should comply with international standards if they do not contradict EU directives and if their application is possible in the current actual stage of Poland's economic development. The Act also intended to establish uniform accounting principles for all entities, to increase the social status of the accounting profession, and to create premises for future synchronization of accounting principles with income tax regulations (Lisiecka-Zajac, 1994). Fundamental accounting principles required to 
be applied include matching principle and accrual basis, ongoing concern, historical cost, conservatism, consistency, and materiality. Reliability and relevance are listed as the most important characteristics of accounting information. The principle of "substance over form" is not mentioned. This principle is of particular significance because it reflects a major departure from the former system in which the focus was on legal form. Polish companies are required to present a balance sheet, income statement, statement of cash flows, and notes and supplementary information in the annual report, which should be prepared on a calendar-year basis. Each company must establish its own chart of accounts. The amount of information which must be disclosed in the notes to the financial statements increased significantly.

The new Act on Accounting enacted in Poland introduced for the first time a requirement to prepare a statement of cash flows. The indirect method is recommended to determine net cash flows from operating activities. The International Accounting Standards Committee (IASC) encourages companies to use the direct method for operating cash flows, a method which is more in conformity with the objectives of the statement to present cash receipts and payments from operating, investing, and financing activities. This method seems also to be more understandable from the user's point of view. Polish officials suggest that the indirect method was recommended because, under this method, the preparation of the statement presents fewer difficulties in practice, which takes into consideration the existing level of accounting education.

Under the new accounting law, Polish companies are required to prepare consolidated financial statements. This requirement is important since the mass privatization program substantially increased the number of enterprises operating as holding companies. Despite the recent changes in accounting and financial reporting standards, revisions are still required to be in full compliance with international standards. Clear standards of accounting for long-term liabilities must be established, i.e., bonds, leases, and deferred taxes, since there was no tradition of accounting for interest under the old system. At the present time, the lack of accounting standards for leases results in the fact that lease-holding companies cannot be registered on the WSE.

Under the new accounting and financial reporting standards, the financial reports prepared by Polish publicly held companies are more 
relevant and reliable in evaluation of their financial position, results of operations, and cash flows. It is expected, therefore, that earnings determined in conformity with these standards should possess information content for securities valuation.

\section{Earnings as an Explanatory Variable for Returns}

\section{A. Sample Selection and Research Design}

This article evaluates an association between stock returns and annual earnings of Polish firms listed on the WSE. The sample includes 52 firms traded during the 1995-97 time period resulting in 139 observations. ${ }^{3}$ Financial firms (banks and insurance companies) are excluded from the sample for two reasons: specific financial attributes of firms in banking and insurance industries may result in different information content of their earnings, and acts and decrees regulating financial reporting in Poland contain specific provisions pertaining to these industries, and controlling for the effect of these provisions would unnecessarily encumber the analysis.

The appendix contains a list of firms included in the sample. Accounting and dividend data were obtained from Notoria Services, which issues quarterly books (and complementary disks) with financial statements and other information about Polish listed companies. Prices were obtained via Internet from the archives of the WSE. Prices, dividends, and accounting data are all in domestic currency -- Polish zloty $(\mathrm{Pzl}){ }^{4}$

Table 3 provides descriptive statistics on four basic characteristics of firms in our sample: (1) total assets (TA), (2) sales, (3) net income (NI), and (4) market capitalization (MC). The sample is further divided, according to market type, into main and parallel subsamples. The mean values of assets, sales, income, and capitalization for these two subsamples were tested for differences using a two-sample $t$-test

3. The original number of 156 observations was reduced by: (1) 15 cases in which opening stock prices for the year 1995 were not available; (2) one case of merger between firms (Polifarb Cieszyn and Polifarb Wroclaw started to report as one firm in 1997); and elimination of one outlying observation (Agros in 1996).

4. The exchange rate as of December, 1998, was around 3.45 Pzl per 1 USD. 
TABLE 3. Descriptive Statistics for Total Sample and Market Type Subsamples, 1995-1997

\begin{tabular}{|c|c|c|c|c|c|}
\hline \multirow{2}{*}{\multicolumn{2}{|c|}{ Variable }} & \multirow{3}{*}{$\begin{array}{l}\text { Total } \\
\text { Sample }\end{array}$} & \multicolumn{2}{|c|}{ Subsample } & \multirow{3}{*}{$\begin{array}{l}\text { Difference in } \\
\text { Means } \\
6.94^{*}\end{array}$} \\
\hline & & & Main & Parallel & \\
\hline TA & $\begin{array}{l}\text { Mean } \\
\text { Std. dev. }\end{array}$ & & 253,147 & 44,425 & \\
\hline SALES & $\begin{array}{l}\text { Mean } \\
\text { Std. dev. }\end{array}$ & $\begin{array}{l}286,040 \\
359,750\end{array}$ & 313,905 & 86,072 & $6.36^{*}$ \\
\hline NI & $\begin{array}{l}\text { Mean } \\
\text { Std. dev. }\end{array}$ & $\begin{array}{l}10,916 \\
18,466\end{array}$ & 11,975 & 3,322 & $4.58 *$ \\
\hline $\mathrm{MC}$ & $\begin{array}{l}\text { Mean } \\
\text { Std. dev. }\end{array}$ & $\begin{array}{l}233,056 \\
331,846\end{array}$ & 259,051 & 46,510 & $6.42 *$ \\
\hline
\end{tabular}

Note: Variables: TA (Total Assets), Sales, NI (Net Income), and MC (Market Capitalization) are in '000 Pzl; *Statistically significant at the 5\% level and is a two-tailed test.

(assuming unequal variances). As expected based on capital market regulation summarized in table 1 , all four differences are statistically significant at the $5 \%$ level.

This article is based on a theoretical model which expresses price as a multiple of earnings. This framework is generally used to prompt empirical tests of the relationship between securities returns and change in earnings or between abnormal returns and unexpected earnings (e.g. Beaver, Lambert, and Morse [1980]; Collins and Kothari [1989]). Easton and Harris (1991), using a formal valuation model developed by Ohlson (1995), showed that earnings level, scaled by opening share price, is also a relevant explanatory variable for returns.

Ohlson and Shroff (1992) suggested that inclusion of scaled earnings levels helps reduce misspecification due to measurement error in unexpected earnings (when earnings changes display positive serial correlation). Ali and Zarowin (1992) have subsequently confirmed this hypothesis.

Based on these advances in the earnings-returns research, value relevance of annual earnings was tested by estimating the following regression equation: 


$$
R_{j, t}=\beta_{0}+\beta_{1}\left[\frac{E P S_{j, t}}{P_{j, t-1}}\right]+\beta_{2}\left[\frac{\Delta E P S_{j, t}}{P_{j, t-1}}\right]+\varepsilon_{j, t},
$$

where

$R_{j, t} \quad$ is the stock return for firm $j$ accumulated over an annual window $t$, computed as : $\left(P_{j, t}+D P S_{j, t}-P_{j, t-1}\right) / P_{j, t-1}$,

$P_{j, t-1} \quad$ is the market share price of firm $j$ at the end of year $t-1$ (opening price for year $t$ ),

$D P S_{j, t} \quad$ is dividends paid per share of firm $j$ over time period $t-1$ to $t$,

$E P S_{j, t} \quad$ is the reported $E P S$ of firm $j$ in fiscal year $t$, and

$\triangle E P S_{j, t}$ is the change in reported earnings of firm $j$ for fiscal years $t$ and $t-1$.

The opening share price is used as a deflator to control for size effect and reduce heteroscedasticity. This deflator is suggested by Christie (1987) as the best way to reduce scale effects in returns studies.

The size-related differences in the returns-earnings relation are addressed more explicitly by incorporating in the model a dummy variable representing large firms. Large firms are defined here as those having the value of a particular size variable greater than the mean value for the whole sample. Three size variables, (1) market capitalization, (2) total assets, and (3) sales, are used to estimate the following model:

$$
\begin{gathered}
R_{j, t}=\beta_{0}+\beta_{1}\left[\frac{E P S_{j, t}}{P_{j, t-1}}\right]+\beta_{2}\left[\frac{\Delta E P S_{j, t}}{P_{j, t-1}}\right]+\beta_{3} S_{j, t} \\
+\beta_{4} S_{j, t}\left[\frac{E P S_{j, t}}{P_{j, t-1}}\right]+\beta_{5} S_{j, t}\left[\frac{\Delta E P S_{j, t}}{P_{j, t-1}}\right]+\varepsilon_{j, t},
\end{gathered}
$$

where $S_{j, t}$ is the dummy variable taking the value of 1 if the value of a size variable for firm $j$ in the fiscal year $t$ is greater than the mean value for the whole sample; and the value of 0 otherwise. The $S_{j, t}$ is intended to test for size effects on the intercept and slopes of the explanatory variables in equation 1. 
TABLE 4. Summary Statistics for Variables used in the Regression Analysis (Total Sample)

\begin{tabular}{lcccr}
\hline Variable & Mean & Median & Mode & $\begin{array}{c}\text { Standard } \\
\text { Deviation }\end{array}$ \\
\hline Opening Price & 30.7 & 17.6 & 16.2 & 38.45 \\
$D P S$ & .32 & .00 & .00 & 1.02 \\
Return & .22 & .1 & $\mathrm{n} / \mathrm{a}$ & .62 \\
$E P S$ & 1.21 & 1.13 & 1.13 & 4.66 \\
$E P S / P_{t-1}$ & .12 & .08 & $\mathrm{n} / \mathrm{a}$ & 1.14 \\
$\triangle E P S / P_{t-1}$ & .11 & .01 & $\mathrm{n} / \mathrm{a}$ & 1.18 \\
\hline
\end{tabular}

The main size effect and the interaction terms in the model allow for the possibility that the relationships between the earnings levels and the returns, and between the earnings changes and the returns, are firm-sizedependent. The response function for small firms has $\beta_{0}$ intercept, $\beta_{1}$ earnings level slope, and $\beta_{2}$ earnings change slope. The response function for large firms has $\beta_{0}+\beta_{3}$ intercept, $\beta_{1}+\beta_{4}$ earnings level slope, and $\beta_{2}+\beta_{5}$ earnings change slope. Thus, $\beta_{4}$ and $\beta_{5}$ indicate how much greater (smaller) are the earnings level and change slopes for the large firms than for the small firms. We expect these differential coefficients, $\beta_{4}$ and $\beta_{5}$, to be significantly different from zero.

The association between earnings and returns is measured over an annual window, covering the fiscal year. The choice of the fiscal year rather than the window covering the financial reporting period (often used in the U.S.) came from our consulting with insiders at the Polish Ministry of Finance, who informed us that the financial results of listed firms are in public domain immediately at the end of the fiscal year. We thus expect the return measure to fully reflect the information contained in annual earnings.

\section{B. Results}

Summary statistics for our variables are provided in table 4 . The test statistics for normality indicate that the data do not depart, to any significant degree, from the normal distribution. The results of bivariate correlation analysis are presented in table 5 . These results provide preliminary evidence that returns are positively correlated with the 
TABLE 5. Bivariate Correlation Matrix

\begin{tabular}{lcccr}
\hline & \multicolumn{5}{c}{ Correlation Coefficients } \\
\cline { 2 - 5 } & $R_{j, t}$ & $E P S_{j, t}$ & $E P S_{j, t} / P t_{-1}$ & \multirow{2}{*}{$\Delta E P S_{j, t} / P_{t-1}$} \\
\hline$R_{j, t}$ & 1 & & & \\
$E P S_{j, t}$ & .2584 & 1 & & \\
$E P S_{j, l} / P_{t-1}$ & .2908 & .1866 & 1 & 1 \\
$\Delta E P S_{j, t} / P_{t-1}$ & .2282 & .0835 & .8420 & 1 \\
\hline
\end{tabular}

Note: $R_{j, t}$ is the stock return for firm $j$ accumulated over an annual return window $t$, computed as follows: $\left(P_{j, t}+D P S_{j, t}-P_{j, t-1}\right) / P_{j, t-1}, E P S_{t}$ is the reported $E P S$ of firm $j$ in fiscal year $t$, and $P_{t-1}$ is the market share price at the end of year $t-1$ (opening price for year $t$ )

scaled earnings level and their change. ${ }^{5}$

Table 6 presents the estimates for the model given in equation 1 . Simple regressions results for the whole sample (panel A, models 1d and 2) show that the earnings level explains about 8 percent of the variation in annual returns while only 5 percent of this variation are attributed to the change in reported earnings. When considered separately, both earnings variables have significant information content.

The multiple regression results (panel A, model 3) indicate that the two independent variables are jointly significant, as the $F$-value shows the null hypothesis that $\beta_{1}=\beta_{2}=0$ easily rejected at the $1 \%$ level. The $t$-values for individual coefficients suggest, however, that earnings change does not contain any incremental information beyond what is included in earnings level. ${ }^{6}$ Overall, the adjusted $R^{2}$ s for simple and multiple regression models are very similar to those of comparable returns-earnings studies in more advanced economies. ${ }^{7}$

5. Multicollinearity tests were performed and mild collinearity was found between the independent variables. Although it was expected that earnings level and change capture a certain degree of common information, the multicollinearity effect in the sample is somewhat exacerbated by a limited sample size. Multicollinearity does not bias the estimators of partial slope coefficients in a regression model. However, it influences the variance of the estimated coefficients and impairs the significance tests and confidence intervals for these coefficients. Therefore, although partial-slope coefficient estimators remain unbiased, they are less efficient (Berry and Feldman [1991]).

6. In other studies of similar design conducted in more mature markets,the earnings level variable also tends to be more important in explaining variation in returns than the earnings change variable. Furthermore, the earnings change coefficient tends to be negative for some subsamples (Easton and Harris [1991]; Alford et al. [1993]).

7. Easton and Harris (1991) tested identical simple and multiple regression models on 19,996 observations for U.S. firms listed between 1968-1986; their adjusted $R^{2}$ s for pooled 
TABLE 6. Simple and Multiple Regression Analysis, 1995-97

\begin{tabular}{|c|c|c|c|}
\hline & \multicolumn{2}{|c|}{$R_{j, t}=\beta_{0}+\beta_{1}\left[E P S_{j, t} / P_{j, t-1}\right]+\beta_{2}\left[\Delta E P S_{j, l} / P_{j, t-1}\right]+\varepsilon_{j, t}$} & \multirow{2}{*}{$\begin{array}{r}(1) \\
\text { Model } 3\end{array}$} \\
\hline & Model 1 & Model 2 & \\
\hline \multicolumn{4}{|c|}{ A. Total sample: 139 observations (coefficients and $t$-values) } \\
\hline \multirow{2}{*}{$\beta_{0}$} & .2002 & .2065 & .2003 \\
\hline & $(3.96)^{*}$ & $(4.02)^{*}$ & $(3.95)^{*}$ \\
\hline \multirow[t]{2}{*}{$\beta_{1}$} & .1583 & & .1845 \\
\hline & $(3.56)^{*}$ & & $(2.23)^{*}$ \\
\hline \multirow[t]{2}{*}{$\beta_{2}$} & & .12 & -.0301 \\
\hline & & $(2.74)^{*}$ & $(-.38)$ \\
\hline Adj. $R^{2}$ & .08 & .05 & .07 \\
\hline$F$-value & $12.66^{*}$ & $7.53^{*}$ & $6.36^{*}$ \\
\hline \multicolumn{4}{|c|}{ B. Main market subsample: 122 observations (coefficients and $t$-values) } \\
\hline \multirow[t]{2}{*}{$\beta_{0}$} & .1764 & .1812 & .1768 \\
\hline & $(3.97)^{*}$ & $(3.59)^{*}$ & $(3.56)^{*}$ \\
\hline \multirow[t]{2}{*}{$\beta_{1}$} & .1542 & & .1782 \\
\hline & $(3.78)^{*}$ & & $(2.35)^{*}$ \\
\hline \multirow[t]{2}{*}{$\beta_{2}$} & & .1175 & -.0275 \\
\hline & & $(2.92)^{*}$ & $(-.38)$ \\
\hline Adj. $R^{2}$ & .1 & .06 & .09 \\
\hline$F$-value & $14.31^{*}$ & $8.51 *$ & $7.18^{*}$ \\
\hline \multicolumn{4}{|c|}{ C. Parallel market subsample: 17 observations (coefficients and $t$-values) } \\
\hline \multirow[t]{2}{*}{$\beta_{0}$} & -.1999 & .2615 & -.1094 \\
\hline & $(-.67)$ & $(1.33)$ & $(-.22)$ \\
\hline$\beta_{1}$ & $\begin{array}{l}4.8765 \\
(2.52)^{*}\end{array}$ & & $\begin{array}{l}3.8745 \\
(.8)\end{array}$ \\
\hline \multirow[t]{2}{*}{$\beta_{2}$} & & 4.2581 & 1.0109 \\
\hline & & $(2.35)^{*}$ & $(.23)$ \\
\hline Adj. $R^{2}$ & .25 & .22 & .20 \\
\hline$F$-value & $6.37 *$ & $5.51 *$ & $3.01 * *$ \\
\hline
\end{tabular}

Note: $* * *$ Statistically significant at the $5 \%$ level and the $10 \%$ level, respectively.

sample were: (1).075 (earnings level only), (2)0.040 (earnings change only), and (3).077 (earnings level and change); the maximum (minimum) adjusted $R^{2} \mathrm{~s}$ for individual years were (1) .230 (.033), (2) .157 (.008), and (3).231 (.032), respectively. Because of the extremely large size of the sample, their study did not suffer from any multicollinearity problem, and the multiple regression model represented improvement over both simple regressions. Alford et al. (1993) tested a similar model on multiple samples of non-U.S. firms classified by country. Their slope $R^{2}$ s ranged from a minimum of .027 (Sweden) to a maximum of .261 (United Kingdom). 
Also, the main market firms were separated from the parallel market firms and the subsamples data were fitted to the same simple and multiple regression models. Results for the main market subsample are presented in panel B while results for the parallel market subsample are presented in panel C.

Results for the main market are slightly stronger than for the whole sample and definitely stronger than for the parallel market. The two independent variables explain $9 \%$ of variation in returns and, again, only the scaled earnings level is significant at the $5 \%$ level. Goodness of fit of the model, as assessed by the $F$-value, is diminished when the model is fit to the data for the parallel market. ${ }^{8}$ Individual coefficients of earnings level and change are also less significant. The stronger information content of earnings reported by firms traded on the main market may indicate that investors have more confidence in their reports as compared to reports provided by firms traded on the parallel market. This is not a surprise, as the firms admitted for trading on the main market are larger, stronger, and more profitable. Also, the disclosure requirements at the time of admission to the main market are more extensive (refer to table 1).

In the next step, a multiple regression test was performed for each year separately and the results are compared with the pooled sample results. This comparison is presented in table 7.

The results for 1995 indicate that none of the coefficients is significantly different from zero, and the model poorly fits the data, as evidenced by low adjusted $R^{2}$ and $F$-value. The results definitely improve the the following two years (1996 and 1997). The year 1996 is the best of the three with both earnings variables explaining 14 percent of variation in the annual returns. The poor showing for 1995 can be attributed to: (1) a smaller sample size than in the two following years, (2) investors' confusion as a result of an introduction of the new accounting rules, and/or (3) the relatively lower sophistication of investors at the earlier stages of capital market development in Poland.

In order to directly incorporate size effect into the study, model 2 was tested three times, using the following size variables: (1) market capitalization, (2) total assets, and (3) sales. The results are presented

8. In evaluating goodness of fit of the model for the parallel market, we do not rely on $R^{2}$ statistic because of the small sample size. The $R^{2}$ increases when observations are taken at only a few levels of the independent variables. 
TABLE 7. Multiple Regression Analysis: Pooled vs. Annual Cross-Sectional Data

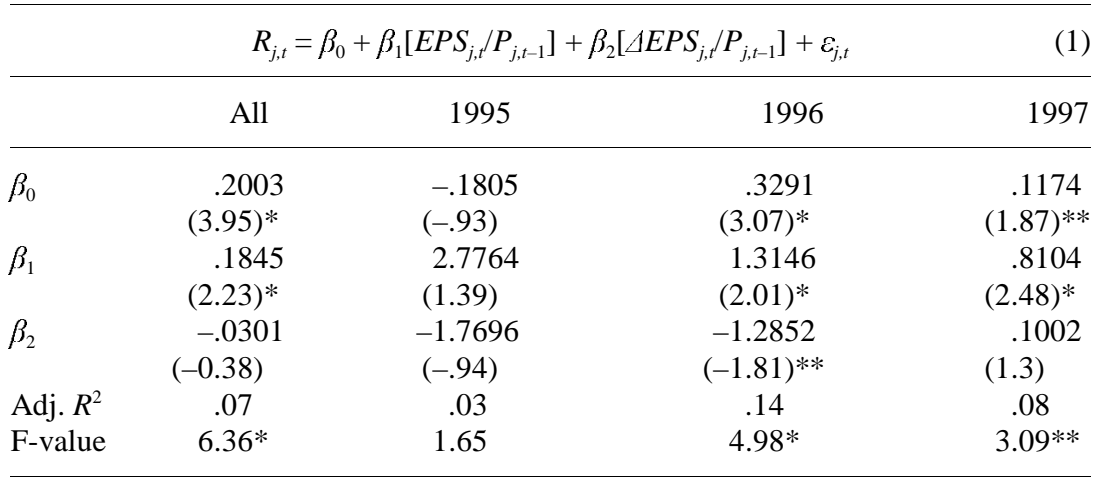

Note: *** Statistically significant at the $5 \%$ level and the $10 \%$ level, respectively.

in table 8 .

The best fit was obtained when firm size was measured by market capitalization (panel A). The adjusted $R^{2}$ more than doubled, as compared to the results for model 3 in table 6 . The coefficient on the earnings level for small firms $\beta_{1}$ is positive and significant at the $5 \%$ level. As expected, the differential coefficient $\beta_{4}$ is positive and significant at the $.1 \%$ level. This implies that the information content of the earnings level of large firms is significantly greater than that of small firms.

The coefficient on the earnings changes for small firms $\beta_{2}$ is negative and insignificant, as expected from the full sample results. The differential coefficient $\beta_{5}$ is positive but insignificant. This result confirms the earlier conclusion that earnings changes do not possess incremental information beyond what is contained in earnings level.

The other two size variables (total assets and sales) did not enhance a goodness of fit of model 1. Results for model 2 incorporating these two size measures are presented in panels B and C.

\section{Summary and Conclusions}

One of the most important consequences of privatization and development of the capital market in Poland was a far-reaching 
TABLE 8. Firm Size Analysis

\begin{tabular}{|c|c|c|c|c|c|c|c|}
\hline \multirow{2}{*}{$\beta_{0}$} & \multicolumn{5}{|c|}{ Coefficients and $t$-values } & \multirow[b]{2}{*}{ Adj. $R^{2}$} & \multirow[b]{2}{*}{ F-value } \\
\hline & $\beta_{1}$ & $\beta_{2}$ & $\beta_{3}$ & $\beta_{4}$ & $\beta_{5}$ & & \\
\hline
\end{tabular}

A. Size measured by market capitalization

$\begin{array}{lrrrrrrr}.1471 & .1720 & -.017 & -.3518 & 8.0989 & .0815 & & \\ (2.6)^{*} & (2.19)^{*} & (-.22) & (-2.03)^{*} & (3.9) & (.05) & .17 & 6.61\end{array}$

B. Size measured by total assets

$\begin{array}{llllllll}.1973 & .1764 & -.0242 & -.1466 & 2.5754 & -1.3079 & & \\ (3.21) & (2.13)^{*} & (-.3) & (-1.05) & (1.79)^{*} & (-1.06) & .07 & 3.23\end{array}$

C. Size measured by sales

\begin{tabular}{llllllll}
.1868 & .1775 & -.0244 & -.0693 & 1.9708 & -.8347 & & \\
$(3.13)$ & $(2.14)^{*}$ & $(-.3)$ & $(-.48)$ & $(1.39)$ & $(-.7)$ & .07 & $3.01 *$ \\
\hline
\end{tabular}

Note: *** Statistically significant at the $5 \%$ level and the $10 \%$ level, respectively.

restructuring of the Polish accounting system. In order to accommodate the new objectives of the accounting system and the new users of the financial statements in the market economy (investors, creditors, and suppliers), previous accounting regulations were changed, and accounting was defined much more comprehensively.

The findings provide evidence that the annual earnings reported according to new accounting rules by firms listed on the WSE are an important element of the valuation process. The findings compare closely with the results found in more mature capital markets. This similarity is particularly striking when the results are compared to those for other European countries, such as France, Germany, Belgium, and Italy (Alford et al., 1993). After all, despite national and historical differences, environmental influences on accounting in Poland and in those countries are quite common, including legal and political systems, culture and social climate (Adams and McMillan, 1997).

It is particularly surprising that the findings are similar to those found by Easton and Harris (1991), who tested the association between earnings and returns in the mature, sophisticated U.S. capital market. 
Although coefficients in their study are consistently higher, signaling stronger influence of earnings on prices, the explanatory power of earnings for returns is quite similar, as measured by the magnitude of $R^{2}$ s. We interpret this as evidence that earnings reported under the new measurement and disclosure requirements in Poland perform a valuation role similar to those in advanced markets.

This study can be used to motivate subsequent studies of information content, controlling for specific events that might trigger trades driven purely by investor psychology. Gordon and Rittenberg (1995) analyzed the behavior of Polish investors in light of the efficient market hypothesis (EMH). They argued that the current regulations, including pricing limits and reduction orders, inhibit Polish stock prices from truly reflecting changes in information. They concluded that the role of investors' psychology appears to be more significant than the rational evaluation of available information.

Without challenging this view, it should be noted that Gordon and Rittenberg's study covers the introductory years of the WSE that is 1993-94. To the contrary, there is still vast anecdotal evidence of irrational investors' behavior in Poland. For example, in 1996, the shares of ESPEBEPE-Holding S.A. (trade, construction) were still listed on the WSE and share prices remained stable although the company already had become insolvent and legal proceedings were initiated by creditors. On the other hand, however, it can be argued that a noticeable relationship between the behavior of investors and actual market performance is observable in much more developed markets as well.

The study analyzed the relationship between earnings and returns over a long annual window. Further research, including event studies, is necessary to determine the efficiency of the Polish capital market. Moreover, an integration and interaction of WSE with other capital markets should also be of great interest.

\section{Appendix}

Names of Companies in the Sample

\begin{tabular}{ll} 
Name & Industry \\
\hline 1. Agros & trade \\
2. Animex & trade \\
3. Beton Stal & construction
\end{tabular}


4. Budimex

5. Bytom

6. Computerland

7. Debica

8. Domplast

9. Drosed

10. Efekt

11. Elektrim

12. Elektromontaz-Exp

13. Espebepe

14. Exbud

15. Farm Food

16. Gorazdze

17. Indykpol

18. Irena

19. Jelfa

20. Jutrzenka

21. Kabel BFK

22. Kable SFK

23. KPBP-Bick

24. Krakchemia

25. Krosno

26. Mostostal-Exp

27. Mostostal-Gdansk

28. Mostostal-Waw

29. Mostostal-Zab

30. Novita

31. Okocim

32. Optimus

33. Pekpol

34. Polfa-Kutno

35. Polifarb-CN

36. Polifarb-Wr

37. Prochem

38. Prochnik

39. Rafako

40. Remak

41. Rolimpex

42. Sokolow

43. Stalexport

44. Stomil

45. Swarzedz

\author{
construction \\ textiles \\ computers \\ chemical \\ chemical \\ confectionery \\ trade \\ trade \\ construction \\ construction \\ construction \\ agricultural/meat products \\ chemical \\ agricultural/poultry \\ glass \\ chemical \\ confectionery \\ electrical \\ electrical \\ construction \\ trade \\ chemical \\ construction \\ construction \\ construction \\ construction \\ light industry/furnishings \\ brewing \\ computers \\ agricultural/meat products \\ pharmaceutical \\ chemical \\ chemical \\ construction \\ textiles \\ electrical \\ electrical \\ trade \\ agricultural \\ trade \\ chemical \\ furniture
}


46. Tonsil

47. Universal

48. Vistula

49. Wedel

50. Wolczanka

51. Zasada

52. Zywiec electrical

trade

textiles

confectionery

textiles

automobile

brewing

\section{References}

Act on Accounting (Ustawa o Rachunkowosci), Poland, 1994.

Adams, C. A., and McMillan, K. M. 1997. Internationalizing financial reporting in a newly emerging market economy: The Polish example. Advances in International Accounting 10: 139-164.

Alford, A.; Johns, J.; Leftwich, R.; and Zmijewski, M. 1993. The relative informativeness of accounting disclosures in different countries. Journal of Accounting Research 31 (Supplement): 183-223.

Ali, A. and Zarowin, P. 1992. The role of earnings levels in annual earningsreturns studies. Journal of Accounting Research 30 (Autumn): 286-295.

Beaver, W. H.; Lambert, R.; and Morse, D. 1980. The information content of security prices. Journal of Accounting and Economics 2: 3-28.

Berry, W. D., and Feldman, S. 1991. Multiple Regression in Practice. Sage University Paper series on Quantitative Applications in the Social Sciences, series no. 07-050. Newbury Park and London: Sage Publications, Inc.

Christie, A. 1987. On cross-sectional analysis in accounting research. Journal of Accounting \& Economics 9 (December): 231-258.

Collins, D. W. and Kothari, S. P. 1989. An analysis of intertemporal and crosssectional determinants of earnings response coefficients. Journal of Accounting \& Economics 11 (July): 143-181.

Easton, P. D. and Harris, T. S. 1991. Earnings as an explanatory variable for returns. Journal of Accounting Research 29 (1): 19-36.

"Emerging Market Indicators." 1996. The Economist (October 26-November 1): 128 .

Gordon, B. and Rittenberg, L. 1995. The Warsaw Stock Exchange: A test of market efficiency. Comparative Economic Studies 2: 1-27.

International Accounting Standards 1998. International Accounting Standards Committee.

Koc, S. and Borkowska, M. 1994. Rachunkowosc w swietle uregulowan Ustawy: Co zmienia sie od 1995 r. (Accounting as regulated by the Act on Accounting: What will change in 1995). Warszawa: Finans-Services.

Lisiecka-Zajac, B. 1994. Ogolna charakterystyka Ustawy o Rachunkowosci 
(General characteristics of the Act on Accounting). Rachunkowosc. Zeszyt Specjalny (Special Edition).

Ohlson, J. A. 1995. Earnings, book values, and dividends in equity valuation. Contemporary Accounting Research (Spring): 661-687.

Ohlson, J. A. and Shroff, P.K. 1992. Changes vs. levels in earnings as explanatory variables for returns: Some theoretical considerations. Journal of Accounting Research 30: 210-226.

Penetrator. 1995. Miesiecznik analiz tendencji rynku kapitalowego. 11 (November): 59.

Penetrator. 1997. Miesiecznik Analiz Tendencji Rynku Kapitalowego. 9 (September): 105.

Rozporzadzenie w sprawie zasad prowadzenia rachunkowosci (Accounting Regulations) 1990 (October 19). Ministry of Finance, Poland.

Thieme, J. 1995. The Legal Structure of the National Investment Funds. Mass Privatization Program Department, Ministry of Privatization, Poland.

World Investment Report. 1994. Transnational Corporations, Employment and the Workplace. New York: United Nations Economic and Social Council, Commission on Transnational Corporations. 